\title{
Benchmark for Tap-Hole Lifecycle Management Practices in Silicomanganese Production When Submerged Arc Furnace Technology of Circular Design is Applied
}

\author{
JOALET DALENE STEENKAMP $\odot,{ }^{1,2,3}$ DEREK ALAN HAYMAN,${ }^{1}$ and \\ PIETER JOHANNES ANDRIES BEZUIDENHOUT ${ }^{1}$
}

1.-MINTEK, 200 Malibongwe Drive, Randburg, South Africa. 2.-University of the Witwatersrand, 1 Jan Smuts Avenue, Johannesburg, South Africa. 3.—e-mail: joalets@mintek.co.za

\begin{abstract}
A holistic conceptualisation of the variables forming part of tap-hole lifecycle management and performance was defined previously for coke bed-based processes in which submerged arc furnace technology of circular design was applied. In the work presented here, the variables were applied to silicomanganese production comparing the tap-hole lifecycle management practices and performance among five furnaces on one site. The quantified independent variables were divided into four functions associated with the tap-hole lifecycle (operations, reline, maintenance, and repair), and a selection of the results is reported here. Having the benchmark available will contribute to comparative studies in future.
\end{abstract}

\section{INTRODUCTION}

The tap-hole lifecycle typically consists of a combination of four functions: operation, relining, maintenance, and repair. ${ }^{1}$ Management practices associated with each of these functions typically form part of day-to-day furnace operations, and benchmarking allows for furnace operators to evaluate their practices against those of their peers. The more participants in a benchmarking exercise, the greater the potential for comparison and therefore for improvement by participants in such an exercise. Nolet ${ }^{2}$ reported on a project where nine plants participated in a study specifically aimed at tap-hole lifecycle management in platinum group metal (PGM) and nickel matte smelting. Her study is an example of across-commodity, across-country, and even across-technology (to some extent) benchmarking exercises.

At the most local scale, furnace operators can compare their practices amongst furnaces operated on one site. The article presented here reports the results of such an exercise conducted in South Africa on a site where silicomanganese (SiMn) is produced using five submerged arc furnaces (SAFs). The aim is to encourage similar work to be done across commodity, especially for coke bed-based ferroalloy production, i.e., SiMn, ferrochromium (FeCr), and high-carbon ferromanganese (HCFeMn) production utilising SAFs of circular design, and across countries, as South Africa currently has only one producer of SiMn. ${ }^{3,4}$

\section{BACKGROUND}

To contextualise the work presented here, a few concepts related to furnace tapping in SiMn production are defined (for more in-depth discussions of these concepts, refer to $\left.{ }^{5,6}\right)$.

Pyrometallurgy is the branch of science and technology concerned with the use of high temperature to extract and purify metals. ${ }^{7}$ Smelting is the liquid state processing applied in pyrometallurgy to extract the alloy from the ore. The alloy is extracted through melting of the ore and chemical reaction with a suitable reductant such as coal. The liquid oxide phase that remains is called slag. To ensure that the slag remains liquid and has properties that support the chemical reactions required, a flux, i.e., quartz is added.

During smelting, the liquid alloy and slag produced gradually fill the furnace with liquid materials. At some stage, the liquid materials have to be removed from the furnace through an action called 
tapping. During tapping, a hole is made in the sidewall of the furnace containment system, allowing for the liquid material to run from the furnace in a controlled fashion. Once the material of choice is removed, the hole is plugged to allow for further build-up of liquid material. The hole made in the process of tapping is referred to as the tap-hole and the material typically used to plug the tap-hole as tap-hole clay.

Physical separation of the alloy from slag is important and the potential first stage of separation is in the liquid phase. In some furnace designs, tapholes are installed at two different vertical positions: a lower level tap-hole through which the alloy is tapped and a high-level tap-hole through which slag is tapped. This tap-hole configuration is referred to as dual-level tapping. The tap-hole configuration acts as a weir for the separation of metal from slag inside the furnace. In other furnace designs, tap-holes are installed at the same level with alloy and slag being tapped from the same taphole. This tap-hole configuration is referred to as single-level tapping. During single-level tapping, the separation of liquid slag from liquid alloy occurs in either the tapping channel (launder) or the containers used to collect the liquid material (ladles and/or pots).

When a series of containers, consisting of a ladle (mainly to collect the alloy) and pot (to collect the bulk of the slag) stacked in cascade configuration is used, the bulk of the separation between the alloy and slag occurs during tapping. In the cascade configuration, the slag and alloy stream runs from the tap-hole via the launder into the ladle. As the density of slag is typically $50 \%$ less than that of the alloy, the slag will overflow into the pot once the ladle is full. The bulk of the separation between the alloy and slag occurs in this fashion. Once the taphole has been closed, the remainder of the slag floating on top of the liquid alloy is skimmed off by either slightly tilting the ladle or using a mechanical scraper. For mass balance purposes, the weight of the empty ladle is recorded as well as the weight of the full ladle after skimming. The amount of alloy tapped is then calculated by difference.
In most pyrometallurgical smelters, the furnace containment system consists of a combination of refractory materials-materials that maintain their physical integrity at high temperatures-steel and, in some instances, copper components cooled by water or some other cooling medium. The tap-hole forms part of the containment system and is frequently formed by a specially shaped refractory brick or copper component, or combinations of these, referred to as the tapblock. The side of the tapblock towards the inside of the tapblock is referred to as the hot face and towards the outside, the cold face. When the tapblock consists of a series of blocks, the block towards the cold face is often referred to as the Mickey.

\section{METHOD}

A holistic conceptualisation of the variables forming part of tap-hole lifecycle management and performance was defined previously for coke bedbased processes applied to circular SAFs. ${ }^{5}$ In the research presented here, the holistic conceptualisation was applied in the context of SiMn production in South Africa on a single site using five SAFs.

The dependent variable was tapblock life. The independent variables were chosen to be related to tap-hole lifecycle management. Data were collected through interviewing key operating personnel and studying production records and design drawings. The data were collected during a 3-day plant visit in February 2018. Production data for 2017, during the period 1 January 2017 to 31 January 2018 inclusive, were studied. The averages for all of the variables were calculated on a per-tap basis except where noted and discussed separately.

Table II. Composition of tapped alloy, mass\%

\begin{tabular}{|c|c|c|c|c|c|}
\hline Furnace \# & 1 & 3 & 5 & 6 & 7 \\
\hline Mn & 66.2 & 66.2 & 67.4 & 66.2 & 66.2 \\
\hline $\mathrm{C}$ & 1.7 & 1.7 & 2.3 & 1.7 & 1.7 \\
\hline $\mathrm{Si}$ & 16.4 & 16.4 & 14.5 & 16.6 & 16.5 \\
\hline $\mathrm{Fe}$ & 15.3 & 15.3 & 15.4 & 15.0 & 15.2 \\
\hline
\end{tabular}

Table I. Data on process conditions

\begin{tabular}{|c|c|c|c|c|c|c|}
\hline Variable & Unit & F1 & F3 & F5 & F6 & F7 \\
\hline$p:$ Furnace pressure & $\mathrm{kPA}$ & \multicolumn{5}{|c|}{ All furnaces open to atmosphere } \\
\hline $\begin{array}{l}X \% \text { : concentration of individual components in alloy } \\
\text { or slag determined by bulk chemical analyses } \\
\text { of tapped alloy or slag }\end{array}$ & Mass $\%$ & \multicolumn{5}{|c|}{ See Table II for alloy compositions } \\
\hline$M_{\text {alloy }}:$ Alloy mass per tap (weighed) & Tonnes & 11.6 & 12.3 & 26.2 & 12.5 & 26.3 \\
\hline$M_{\text {slag: }}$ Slag mass per tap (estimated) & Tonnes & 13.0 & 13.3 & 28.3 & 13.9 & 28.7 \\
\hline Total mass per tap (weighed) & Tonnes & 24.6 & 25.5 & 54.5 & 26.4 & 55.0 \\
\hline$T_{\text {alloy }} / T_{\text {slag: }}:$ Alloy/slag tap temperature & ${ }^{\circ} \mathrm{C}$ & \multicolumn{5}{|c|}{ Neither alloy nor slag tap temperatures were measured } \\
\hline
\end{tabular}


Table III. Data on tap-hole operations

\begin{tabular}{|c|c|c|c|c|c|c|}
\hline Variable & Unit & F1 & F3 & F5 & F6 & F7 \\
\hline$t_{\text {tap }}:$ Tap duration & Minutes & 31.3 & 30.2 & 34.1 & 24.0 & 30.6 \\
\hline$T R:$ Tap rate & Tonnes/minute & 0.8 & 0.9 & 1.6 & 1.1 & 1.8 \\
\hline$T H_{\text {cf: }}$ Tap-hole cycle frequency (when more than one tap-hole) & Taps/tap-hole & N/A & N/A & N/A & N/A & N/A \\
\hline
\end{tabular}

Table IV. Data on tap-hole drilling parameters

\begin{tabular}{|c|c|c|c|c|c|c|}
\hline Variable & Unit & F1 & F3 & F5 & F6 & F7 \\
\hline Drilling applied & Yes/no & Yes & Yes & Yes & Yes & Yes \\
\hline Drill duty & Number of tap-holes serviced/drilled & One & One & One & One & One \\
\hline Drill support configuration & & Pedestal & Rail & Pedestal & Pedestal & Pedestal \\
\hline Drilling frequency & Tap-hole drilled/tap & One & One & One & One & One \\
\hline Drill depth ${ }^{\#}$ & $\mathrm{~mm}$ & 666 & 677 & $\mathrm{~N} / \mathrm{A}$ & 623 & $\mathrm{~N} / \mathrm{A}$ \\
\hline Drill rod length & $\mathrm{mm}$ & 2500 & 2500 & 2500 & 2500 & 2500 \\
\hline Drill rod diameter & $\mathrm{mm}$ & 32.5 & 32.5 & 32.5 & 32.5 & 32.5 \\
\hline Drill bit diameter (alloy, slag) & $\mathrm{mm}$ & 76 & 76 & 76 & 76 & 76 \\
\hline
\end{tabular}

\#Drill depth measurement had only been implemented during the last 5 weeks of the 12 -month period covered in the analysis. Drill depth measurement had not yet been implemented on furnace \#5 and \#7

Table V. Data on tap-hole lancing parameters

\begin{tabular}{|c|c|c|c|c|c|c|}
\hline Variable & Unit & F1 & F3 & F5 & F6 & F7 \\
\hline Lancing frequency & Tap-hole lanced/tap & \multicolumn{5}{|c|}{ Lancing applied at every tap } \\
\hline Lancing extent & Number of lances/tap & 1.8 & 1.7 & 2.9 & 1.1 & 3.8 \\
\hline Gas used when lancing & \multicolumn{6}{|c|}{ Oxygen } \\
\hline Type of lance used & & \multicolumn{5}{|c|}{ Mild steel } \\
\hline Alloy lance length & $\mathrm{mm}$ & \multicolumn{5}{|c|}{7000} \\
\hline Alloy lance diameter-external and (internal) & $\mathrm{mm}$ & \multicolumn{5}{|c|}{$17(12)$} \\
\hline Reaming of tap-hole applied during tap & Yes/no & \multicolumn{5}{|c|}{ Yes } \\
\hline If ream, type of reaming applied & & \multicolumn{5}{|c|}{ Poking bar } \\
\hline If steel bar applied, diameter of bar & $\mathrm{mm}$ & \multicolumn{5}{|c|}{25} \\
\hline If steel bar applied, length of bar & $\mathrm{m}$ & \multicolumn{5}{|c|}{6} \\
\hline Steel bar consumption per tap & Bars/tap & 1.0 & 1.0 & 1.2 & 1.1 & 1.0 \\
\hline
\end{tabular}

A selection of non-confidential results is presented here as an example of tap-hole lifecycle management and performance in SiMn production in SAFs of circular design.

\section{RESULTS AND DISCUSSION}

Results are presented and discussed according to the four functions associated with tap-hole lifecycle management and performance, namely operation, relining, maintenance, and repair. The definitions and especially mathematical descriptions presented previously are applied. ${ }^{5}$ For ease of comparison, data sets are presented in table format.

\section{Operations}

The variables and associated data associated with tapping operations are presented in a number of tables. Data sets on process conditions, including chemical analyses of the product, are presented in Tables I and II. The data set on tap-hole operations is presented in Table III, on tap-hole drilling 
Table VI. Data on tap-hole clay parameters

\begin{tabular}{|c|c|c|c|c|c|c|}
\hline Variable & Unit & F1 & F3 & F5 & F6 & F7 \\
\hline Tap-hole clay preheated & Yes/no & No & No & No & No & No \\
\hline $\begin{array}{l}\text { Tap-hole clay preheating } \\
\text { method, temperature }\end{array}$ & ${ }^{\circ} \mathrm{C}$ & N/A & N/A & N/A & N/A & N/A \\
\hline $\begin{array}{l}\text { Tap-hole clay composi- } \\
\text { tion-type of aggregate } \\
\text { used }\end{array}$ & & Quartz & Quartz & $\begin{array}{l}\text { Not specified but } \\
\text { contains } \mathrm{SiO}_{2} \text { and } \\
\qquad \mathrm{Al}_{2} \mathrm{O}_{3}\end{array}$ & $\begin{array}{l}\text { Not specified but con- } \\
\text { tains } \mathrm{SiO}_{2}, \mathrm{Al}_{2} \mathrm{O}_{3} \text {, and } \\
\text { C }\end{array}$ & $\begin{array}{l}\text { Silica and alu- } \\
\text { mina raw mate- } \\
\text { rials }\end{array}$ \\
\hline $\begin{array}{l}\text { Tap-hole clay composi- } \\
\text { tion-type of binder } \\
\text { used }\end{array}$ & & Organic & Organic & Tar free & Tar free & Chemical \\
\hline $\begin{array}{r}\text { Tap-hole clay moisture } \\
\text { content }\end{array}$ & Mass $\%$ & \multicolumn{5}{|c|}{ Not reported } \\
\hline Tap-hole clay workability & & $30-36 \%$ & $30-36 \%$ & Not reported & Not reported & $40-50 \%$ \\
\hline $\begin{array}{l}\text { Tap-hole clay consump- } \\
\text { tion }\end{array}$ & $\mathrm{kg} / \mathrm{tap}$ & 41 & 33 & 46 & 36 & 30 \\
\hline
\end{tabular}

\section{Table VII. Data on claygun parameters}

\begin{tabular}{|c|c|c|c|c|c|c|}
\hline Variable & Unit & F1 & F3 & F5 & F6 & F7 \\
\hline Claygun applied & Yes/no & \multicolumn{5}{|c|}{ Yes } \\
\hline Claygun duty & $\begin{array}{l}\text { Number of tap- } \\
\text { holes ser- } \\
\text { viced/claygun }\end{array}$ & \multicolumn{5}{|c|}{ One } \\
\hline Claygun support configuration & & Pedestal & Rail & Pedestal & Pedestal & Pedestal \\
\hline Claygun press-on pressure & $\mathrm{MPa}$ & & & 4.8 & & \\
\hline Claygun nozzle duty & $\begin{array}{l}\text { Tonnes alloy or } \\
\text { slag/nozzle }\end{array}$ & \multicolumn{5}{|c|}{$\begin{array}{c}\text { Replaced once per year or when damaged } \\
\text { when no clay in claygun }\end{array}$} \\
\hline Clay capacity of claygun barrel & Litres & \multicolumn{5}{|c|}{50} \\
\hline Claygun holding time at tap-hole & Minutes & \multicolumn{5}{|c|}{2} \\
\hline Clay injection rate & Litres/second & \multicolumn{5}{|c|}{ Estimated at $3.5-6.0$} \\
\hline Claygun energy supply method & & \multicolumn{5}{|c|}{ Hydraulic } \\
\hline $\begin{array}{l}\text { Methods used to ensure perfect mating between tap- } \\
\text { hole and claygun (mechanical alignment/ceramic or } \\
\text { clay gaskets) }\end{array}$ & & \multicolumn{5}{|c|}{ Swinging in only } \\
\hline Manual plugging applied & Yes/no & \multirow{2}{*}{\multicolumn{5}{|c|}{$\begin{array}{l}\text { Only under emergency conditions, which does } \\
\text { not happen frequently as tapping strategy is to } \\
\text { tap furnace empty at each tap } \\
\text { Form a cone using tap-hole clay, which is then } \\
\text { pushed into the furnace with a round bar to } \\
\text { which a steel disk was attached previously }\end{array}$}} \\
\hline Manual plugging method used & & & & & & \\
\hline
\end{tabular}

parameters in Table IV, on tap-hole lancing parameters in Table $\mathrm{V}$, on tap-hole clay parameters in Table VI, and on claygun parameters in Table VII.

\section{Maintenance}

Tap-hole monitoring practices (which trigger maintenance activities) consist primarily of visual inspections at appropriate intervals as described in
Table VIII below. Simple activities executed in less than $2 \mathrm{~h}$ are considered maintenance activities.

\section{Repair}

Tap-hole monitoring practices (which trigger repair activities) consist primarily of visual inspections at appropriate intervals as described in 


\section{Table VIII. Tap-hole monitoring practices for maintenance}

\begin{tabular}{|c|c|c|c|c|c|}
\hline Variable & F1 & F3 & F5 & F6 & F7 \\
\hline $\begin{array}{l}\text { Tap-hole condition monitoring techniques that trigger } \\
\text { tap-hole maintenance }\end{array}$ & None & None & $\begin{array}{l}\text { Visual inspection, } \\
\text { diameter and shape } \\
\text { of hole }\end{array}$ & None & $\begin{array}{l}\text { Visual inspection, } \\
\text { diameter and shape } \\
\text { of hole }\end{array}$ \\
\hline Tap-hole maintenance intervals & None & None & $\begin{array}{c}\text { Face inspection at } \\
\text { shutdowns }\end{array}$ & None & $\begin{array}{c}\text { Face inspection at } \\
\text { shutdowns }\end{array}$ \\
\hline $\begin{array}{l}\text { Tap-hole maintenance practices including tap-hole } \\
\text { repair, maintenance at the interface between the } \\
\text { tapblock and the claygun }\end{array}$ & None & None & $\begin{array}{l}\text { Replace front } \\
\text { Mickey } \pm \text { every } 8- \\
9 \text { months }\end{array}$ & None & $\begin{array}{l}\text { Replace front } \\
\text { Mickey } \pm \text { every } 8- \\
9 \text { months }\end{array}$ \\
\hline Use of reconstructive tap-hole clays & Yes & Yes & Yes & Yes & No \\
\hline
\end{tabular}

Table IX. Tap-hole monitoring practices for repair

\begin{tabular}{|c|c|c|c|c|c|}
\hline Variable & F1 & F3 & F5 & F6 & F7 \\
\hline $\begin{array}{l}\text { Tap-hole condition } \\
\text { monitoring tech- } \\
\text { niques that trig- } \\
\text { ger tap-hole } \\
\text { repairs }\end{array}$ & \multicolumn{5}{|c|}{ Furnace burn-though (elsewhere or next to tapblock), bricks observed in ladle, visual inspection } \\
\hline $\begin{array}{l}\text { Tap-hole repair } \\
\text { practices }\end{array}$ & $\begin{array}{c}\text { Rebuild by breaking } \\
\text { out refractory until } \\
\text { clean and build from } \\
\text { there } \\
7\end{array}$ & $\begin{array}{c}\text { Rebuild by breaking } \\
\text { out refractory until } \\
\text { clean and build from } \\
\text { there } \\
10\end{array}$ & $\begin{array}{l}\text { Dig out area } \\
\text { below lintel } \\
\text { and reinstall } \\
\text { tapblock } \\
5\end{array}$ & $\begin{array}{l}\text { Rebuild by breaking } \\
\text { out refractory until } \\
\text { clean and build from } \\
\text { there } \\
3\end{array}$ & $\begin{array}{c}\text { Dig out area } \\
\text { below lintel } \\
\text { and reinstall } \\
\text { tapblock } \\
9\end{array}$ \\
\hline
\end{tabular}

Table IX. Complex activities requiring $>2 \mathrm{~h}$ are considered repair activities.

\section{CONCLUSION}

The goal of this research was to support the benchmarking of tap-hole lifecycle management practices in plants producing SiMn using circular SAFs. Specifically, the research output was to create a benchmark for the independent variables that affect tapblock life based on a comparative study conducted on one site that operates five SAFs. The independent variables were identified and described previously. The quantified independent variables were then divided into the four functions associated with the tap-hole lifecycle (operations, reline, maintenance, and repair) and the non-confidential results reported here. Having the benchmark available will contribute in future to comparative analysis studies in the field where confidential results could be shared amongst participants. Potentially, once the data set available is large enough, the effect of the independent variables on tap-hole life can be quantified.

\section{ACKNOWLEDGEMENTS}

This work is published with the permission of MINTEK and Transalloys.

\section{REFERENCES}

1. J.D. Steenkamp, J.J. Sutherland, D.A. Hayman, and J. Muller, JOM 68, 1547 (2016).

2. I. Nolet and J.S. Afr, Inst. Min. Metall. 116, 223 (2014).

3. J.D. Steenkamp, P. Maphutha, O. Makwarela, W.K. Banda, I. Thobadi, M. Sitefane, J. Gous, J.J. Sutherland, and J.S. Afr, Inst. Min. Metall. 118, 309 (2018).

4. J.D. Steenkamp, W.G. Bam, E. Ringdalen, M. Mushwana, S.A.C. Hockaday, N.A. Sithole, and J.S. Afr, Inst. Min. Metall. 118, 645 (2018).

5. J.D. Steenkamp, W.G. Bam, and S.P. Tsebe, JOM 70, 2422 (2018).

6. L.R. Nelson, R. Hundermark, and J.S. Afr, Inst. Min. Metall. 116, 465 (2016).

7. A. Stevenson, eds., Oxford Dictionary of English, 3rd ed. (Oxford: Oxford University Press, 2010).

Publisher's Note Springer Nature remains neutral with regard to jurisdictional claims in published maps and institutional affiliations. 